\title{
MAKING STUDENTS ACTIVELY ASK QUESTIONS IN MATHEMATICS CLASSES BASED ON CURRICULUM 2013
}

\author{
Mohammad Tohir \\ Mahasiswa Program Pascasarjana Universitas Jember, Indonesia \\ matematohir@gmail.com
}

\begin{abstract}
The use of a scientific approach in learning mathematics still experiences obstacles in realizing it, especially those complained by the teachers in the questioning section. Even in practice, most of the teachers applied the 2013 curriculum, but the content of the activity was applying the Education Unit Level Curriculum. This is not in line with what the government wants. Therefore, the writer will explore how to make students actively ask questions in mathematics class. the results of the study show that based on the findings of two research results in two different agencies, namely: (1) six main points that must be known and understood by the teacher, and (2) nine specific points that must be done by the teacher in the questioning activity, dan (3) to make students actively ask questions in math class, the teacher must arrange observational activities as attractive as possible based on the conditions of students in their respective schools and the teacher needs to do these nine specific points when asking questions. In addition, the results of the study indicate that teachers must master and prepare learning models suggested in Curriculum 2013.
\end{abstract}

Keywords: Curriculum, 2013, Mathematics, Scientific Approach, Actively Ask, Learning Model

\section{Conclusion}

Based on the description above, six things need to be done by the teacher to make students actively ask questions in each lesson. Namely (1) the teacher understands about the 2013 curriculum, (2) the teacher needs to make a change in mindset, (3) the teacher understands the scientific approach to learning, (4) the teacher can make interesting observational activities, (5) the teacher must encourage students to ask questions, especially asking investigative questions, and (6) teachers need to understand learning models that can support the application of a scientific approach. Finally, the teacher must apply nine things that can be applied to the activity of asking, namely (1) introducing a certain phenomenon that is interesting and has never been recognized by students before, (2) words in a question, (3) the teacher can give examples of inducement questions, (4) the teacher forms a study group in observing and asking questions, (5) the teacher can also ask students to work in groups to make some questions, (6) the teacher accompanies each student to make questions, (7) completing what if or what if not questions, (8) questioning breakfast, dan (9) questioning appraisal.

Citation: Tohir, Mohammad. (2016). Making Students Actively Ask Questions in Mathematics Classes Based on Curriculum 2013. Proceedings of the National Mathematics Seminar and Learning, ISBN: 987-602-18397-4-4, pp. 249-263. 


\section{Daftar Pustaka}

As'ari, Abdurrahman. (2014). Berbagai Permasalahan Pembelajaran Matematika dalam Kurikulum 2013 dan Beberapa Upaya untuk Mengatasinya. Makalah disajikan dalam Seminar Nasional: Solusi Problematika Implementasi Kurikulum 2013 untuk Mewujudkan Pembelajaran Matematika yang Berkualitas, Program Studi Pendidikan Matematika Universitas Jember pp. 1-13.

As'ari, A. R. (2015). Mewujudkan Pendekatan Saintifik dalam Kelas Matematika. In Makalah dalam Seminar Nasional Pendidikan Matematika, di Universitas Jember.

As'ari, A. R., Tohir, M., Valentino, E., Imron, Z., \& Taufiq, I. (2016). Buku Siswa Matematika SMP/MTs Kelas VII Semester 1. Jakarta: Pusat Kurikulum dan Perbukuan, Balitbang, Kemendikbud.

As'ari, A. R., Tohir, M., Valentino, E., Imron, Z., \& Taufiq, I. (2016). Buku Siswa Matematika SMP/MTs Kelas VII Semester 2. Jakarta: Pusat Kurikulum dan Perbukuan, Balitbang, Kemendikbud.

As'ari, Abdur Rahman, Tohir, M., Valentino, E., Imron, Z., \& Taufiq, I. (2016). Buku Guru Matematika untuk SMP/MtS Kelas VII. Jakarta: Kemdikbud.

As'ari, Abdur Rahman, Tohir, M., Valentino, E., Imron, Z., \& Taufiq, I. (2014). Matematika. Jakarta: Kementerian Pendidikan dan Kebudayaan.

Indonesia, K. P. D. K. R. (2014). Buku Paket Matematika Kelas VIII Kurikulum 2013. Jakarta: Kemdikbud.

Kemendikbud. (2014). Peraturan Menteri Pendidikan dan Kebudayaan, No. 103, Tahun 2014. Jakarta: Kementerian Pendidikan dan Kebudayaan.

Kemendikbud. (2015). Materi Pelatihan Guru Implementasi Kurikulum 2013 Jenjang SMP Tahun 2015. Jakarta: Kementerian Pendidikan dan Kebdayaan.

Laura Bofferding, dkk. (2012). Making Connections Among Student Learning, Content, and Teaching: Teacher Talk Paths in Elementary Mathematics Lesson Study. Journal for Research in Mathematics Education, Vol. 43, No. 5, pp. 616- 650.

Nuh, M. (2014). Buku guru matematika SMP/MTs kelas VIII (Kurikulum 2013). Jakarta: Kementerian Pendidikan dan Kebudayaan.

Pendidikan, K., \& Indonesia, K. R. (2014). Matematika SMP/MTs Kelas VIII Semester 1. Jakarta: Kementrian Pendidikan dan Kebudayaan.

Penulis, T. (2014). Matematika Buku Guru, Kurikulum 2013, Edisi Revisi 2014. Kementerian Pendidikan dan Kebudayaan, p311-353.

Tohir, Mohammad. (2014). Analisis Penerapan Kegiatan Pengamatan Buku Siswa Matematika SMP/MTs Kelas VIII Semester 1 Kurikulum 2013 di SMP Islam Sabilillah Malang. SMP Islam Sabilillah Malang.

Tohir, Mohammad. (2016). Menjadikan Para Siswa Aktif Bertanya dalam Kelas Matematika Berdasarkan Kurikulum 2013. Prosiding Seminar Nasional Matematika dan Pembelajarannya: Peluang Matematika dan Pembelajarannya dalam Menghadapi Masyarakat Ekonomi ASEAN (MEA). Pendidikan Matematika FKIP Universitas Jember.

Tohir, Mohammad. (2016). Penerapan Pendekatan Saintifik pada Pembelajaran Matematika Ditinjau dari Sikap Kritis Siswa Kelas VIII MTs Raudlatul Hasanah Pamekasan. MTs Raudlatul Hasanah Pamekasan. 